\title{
The Effect Of Muḍārabah Financing And Musyārakah Financing On Operational Revenue Of Sharia People Financing Bank (BPRS In Indonesia 2014-2018 Period)
}

\author{
Mariati $^{1}$, Abdul Nasser Hasibuan ${ }^{2}$, Idris Saleh, M. Fauzan ${ }^{4}$ \\ ${ }^{1}$ IAIN Padangsidimpuan (Perbankan Syariah, FEBI, IAIN Padangsidimpuan) \\ ${ }^{2}$ IAIN Padangsidimpuan (Perbankan Syariah, FEBI, IAIN Padangsidimpuan) \\ ${ }^{3}$ IAIN Padangsidimpuan (Perbankan Syariah, FEBI, IAIN Padangsidimpuan) \\ ${ }^{4}$ IAIN Padangsidimpuan (Perbankan Syariah, FEBI, IAIN Padangsidimpuan) \\ mariati@gmail.com $^{1}$, hasibuanabdulnasser @iain-padangsidimpuan.ac.id ${ }^{2}$, idrissale@iain- \\ padangsidimpuan.ac.id $^{3}$, fauzan@iain-padangsidimpuan.ac.id ${ }^{4}$
}

\begin{abstract}
ABSTRAK
Berdasarkan data laporan keuangan pembiayaan Muḍārabah, Musyārakah, dan pendapatan operasional pada Bank Pembiayaan Rakyat Syariah tahun 2014 sampai 2018. Adanya peningkatan pembiayaan tapi tidak diikuti dengan peningkatan pendapatan operasional, dan juga sebaliknya pendapatan operasional mengalami peningkatan tapi pembiayaannya mengalami penurunan. Sehinggga rumusan masalah dalam penelitian ini adalah apakah ada pengaruh pembiayaan Muḍārabah dan pembiayaan Musyārakah terhadap pendapatan operasional pada Bank Pembiayaan Rakyat Syariah. Dengan tujuan penelitian ini adalah untuk mengetahui pengaruh variabel pembiayaan Muḍārabah dan pembiayaan Musyārakah secara parsial dan simultan terhadap pendapatan operasional pada Bank Pembiayaan Rakyat Syariah. Pembahasan penelitian ini berkaitan tentang pembiayaan Muḍārabah dan pembiayaan Musyārakah serta pendapatan operasional Bank Pembiayaan Rakyat Syariah (BPRS) dan dilengkapi dengan ilmu-ilmu lain yang berkaitan dengan topik yang diteliti. Penelitian ini adalah penelitian kuantitatif, dengan menggunakan data sekunder dan bentuk time series dari tahun 2014 sampai 2018 sebanyak 60 sampel. Analisis data yang digunakan adalah uji analisis statistik deskrptif, uji normalitas, uji asumsi klasik (uji multikolinearitas, uji heteroskedastisitas, uji autokolerasi), uji $R^{2}$, uji hipotesis (uji t, uji F), dan uji regresi linier berganda dengan pengolahan digunakan melalui SPSS 23. Hasil penelitian secara parsial (uji t) Tidak terdapat pengaruh pembiayaan Muḍārabah terhadap pendapatan operasional pada Bank Pembiayaan Rakyat Syariah di Indonesia periode 2014-1018. Terdapat pengaruh pembiayaan Musyārakah terhadap pendapatan operasional Bank Pembiayaan Rakyat Syariah di Indonesia periode 2014-2018. Sedangkan secara simultan $F_{\text {hitung }}$ memiliki nilai yang lebih besar dari $F_{\text {tabel }}$ hal ini menjelaskan bahwa pembiayaaan Muḍārabah dan pembiayaan Musyārakah mempunyai pengaruh yang signifikan secara simultan terhadap pendapatan operasional.
\end{abstract}

Kata Kunci: Muḍārabah, Musyārakah, Pendapatan Operasional

\section{ABSTRACT}

Based on the financial report data of Muḍārabah financing, Musyārakah, and operating income in the Islamic People's Financing Bank in 2014 to 2018. An increase in financing but not followed by an increase in operating income, and also vice versa operating 
income has increased but the funding has decreased. So that the formulation of the problem in this research is whether there is an influence of Murārabah financing and Musyārakah financing on operational income at the Islamic People's Financing Bank. With the aim of this study is to determine the effect of Muḍārabah financing and Musyārakah financing partially and simultaneously on operational income at the Islamic People's Financing Bank. The discussion of this study relates to Muḍārabah financing and Musyārakah financing and operational income of the Islamic People's Financing Bank (BPRS) and is complemented by other sciences related to the topic under study. This research is a quantitative study, using secondary data and time series forms from 2014 to 2018 as many as 60 samples. Data analysis used was descriptive statistical analysis test, normality test, classic assumption test (multicollinearity test, heteroscedasticity test, autokoleration test), $\mathrm{R}^{2}$ test, hypothesis test ( $\mathrm{t}$ test, $\mathrm{F}$ test), and multiple linear regression tests with processing used through SPSS 23. Partial research results (t-test) There is no effect of Mudāababah financing on operating income at the Islamic People's Financing Bank in Indonesia for the 2014-1018 period. There is an influence of Musharaka financing on the operational income of Islamic People's Financing Banks in Indonesia for the 2014-2018 period. While simultaneous Fcount has a value greater than Ftable, this explains that Muḍārabah financing and Musyārakah financing have a significant simultaneous effect on operational income.

Keywords: Muḍārabah, Musyārakah, Operating Income

\section{A. PENDAHULUAN}

Kemajuan dan perkembangan bank syariah dalam beberapa tahun terakhir meningkat cukup signifikan. Perkembangan ini tentunya diharapkan akan menjadi peluang yang bagus untuk masa yang akan datang.

Tabel 1.1

Perkembangan Jaringan Kantor Perbankan Syariah Di Indonesia

\begin{tabular}{|c|c|c|c|}
\hline Tahun & BUS/Unit & UUS/ Unit & BPRS/Unit \\
\hline 2014 & 12 & 22 & 163 \\
\hline 2015 & 12 & 22 & 163 \\
\hline 2016 & 13 & 21 & 166 \\
\hline 2017 & 13 & 21 & 167 \\
\hline 2018 & 14 & 20 & 167 \\
\hline
\end{tabular}

Sumber: Statistik Perbankan Syariah OJK 2014-2018

Berdasarkan tabel 1.1 dapat dilihat bahwa pada tahun 2014-2015 Bank Umum
Syariah (BUS) mengalami peningkatan yaitu dari 12 unit untuk tahun 2014-2015 menjadi 14 unit pada tahun 2018. Sedangkan bank konvensional yang membuka Unit Usaha Syariah (UUS) dari tahun 2014-2015 mengalami penurunan yaitu dari tahun 2014-2017 berjumlah 22 unit, kemudian pada tahun 20162017 menjadi 21 unit, dan ditahun 2018 menjadi 20 unit. Kemudian Bank Pembiayaan Rakyat Syariah (BPRS) juga mengalami peningkatan dari tahun 2014-2015 berjumlah 163 unit pada tahun 2016 berjumlah 166 unit dan pada tahun 2017-2018 menjadi 167 unit. Hal tersebut menunjukkan bahwa diantara BUS 
Mariati ${ }^{1}$, Abdul Nasser Hasibuan ${ }^{2}$, Idris Saleh ${ }^{3}$, M. Fauzan ${ }^{4}$

POINT Vol. 2, No. 2, Des 2021

dan UUS yang paling berkembang pesat yaitu BPRS.

Kegiatan usaha BPRS menurut Undang-

Undang No.21 tahun 2008 tentang Perbankan

syariah yaitu menyalurkan dana kepada

masyarakat dalam bentuk pembiayaan

berdasarkan akad Muḍārabah dan Musyārakah

dan pembiayaan berdasarkan akad Murābahah,

Salam, dan Istishna'. Sedangkan untuk

penghimpunan dana salah satunya dengan akad

Muḍārabah (Sutan Remy Sjahdeini, 2014:106107).

Berdasarkan data laporan keuangan pembiayaan Muḍāabah, Musyārakah, dan pendapatan operasional pada Bank Pembiayaan Rakyat Syariah(BPRS) yang di publikasikan di www.ojk.go.id tahun 2014 sampai 2018. Adanya peningkatan pembiayaan tapi tidak diikuti dengan peningkatan pendapatan operasional, dan juga sebaliknya pendapatan operasional mengalami peningkatan tapi pembiayaannya mengalami penurunan. Sehinggga rumusan masalah dalam penelitian ini adalah apakah ada pengaruh pembiayaan Muḍārabah dan pembiayaan Musyārakah terhadap pendapatan operasional pada Bank
Pembiayaan Rakyat Syariah. Dengan tujuan

penelitian ini adalah untuk mengetahui pengaruh variabel pembiayaan Muḍārabah dan pembiayaan Musyārakah secara parsial dan simultan terhadap pendapatan operasional pada Bank Pembiayaan Rakyat Syariah.

\section{B. METODE}

1. Lokasi dan waktu penelitian

Penelitian ini dilaksanakan pada Bank Pembiayaan Rakyat Syariah (BPRS) melalui website resmi www.ojk.go.id (otoritas jasa keuangan). Adapun waktu penelitian ini dimulai dari bulan September 2019 sampai dengan Desember 2019.

2. Jenis Penelitian

Dalam penelitian ini menggunakan penelitian kuantitatif. Penelitian kuantitatif adalah penelitian yang menggunakan data kuantitatif (data berbentuk angka atau data yang di angkakan). Metode ini sebagai metode ilmiyah karena telah memenuhi kaidah-kaidah ilmiyah yaitu konkrit, objektif, terukur, rasional, dan sistematis. Pengumpulan data menggunakan instrument penelitian, serta dengan tujuan untuk menguji hipotesis yang 
telah ditetapkan. Adapun penelitian ini dilakukan berdasarkan time series atau disebut juga deret waktu merupakan sekumpulan data dari suatu fenomena tertentu yang didapat dalam beberapa interval waktu tertentu, misalnya dalam mingguan, bulanan, atau tahunan (Husein Umar, 2013: 42).

3. Populasi dan Sampel

Populasi adalah keseluruhan gejala atau satuan yang ingin diteliti (Bambang prasrtiyo, 2007: 119). Menurut sugiono Populasi adalah wilayah generalisasi yang terdiri atas: obyek/subyek yang mempunyai kualitas dan karakteristik tertentu yang ditetapkan oleh peneliti untuk dipelajari dan kemudian ditarik kesimpulannya (Sugiyono, 2007: 119). Sedangkan populasi dalam penelitian ini adalah seluruh laporan keuangan publikasi bulanan Bank Pembiayaan Rakyat Syariah yang berkenaan dengan penyaluran pembiayaan Muḍārabah, dan Musyārakah serta pendapatan operasional Bank Pembiayaan Rakyat Syariah dari tahun 2014-2018 menjadi 5 tahun dengan laporan keuangan publikasi bulanan yang berjumlah 60 bulan.
Sampel adalah suatu himpunan bagian dari unit populasi. Sampel berarti contoh, yaitu sebagian individu yang menjadi objek penelitian. Tujuan penting sampel ini adalah untuk memperoleh keterangan mengenai objek penelitian dengan cara mengamati hanya sebagian dari populasi.

Dalam penelitian ini peneliti menggunakan desain sampling Jenuh. Sampling Jenuh adalah tehnik pengambilan sampel bila semua anggota populasi digunakan sebagai sampel (Sugiyono, 2007: 68). Sampel penelitian ini adalah seluruh seluruh populasi dalam 5 tahun dari tahun 2014-2018. Total sampel yang akan diambil dalam penelitian ini yaitu laporan keuangan publikasi bulanan Bank Pembiayaan Rakyat Syariah yang berjumlah 60 sampel. Jadi penelitian ini adalah penelitian populasi.

4. Sumber Data

Penelitian ini menggunakan data skunder, yaitu jenis data primer yang telah diolah lebih lanjut dan disajikan baik oleh pihak pengumpulan data primer atau oleh pihak lain misalnya dalam bentuk tabel-tabel atau diagram-diagram (Husein Umar, 2013: 42). Data skunder ini digunakan oleh peneliti untuk 
Mariati ${ }^{1}$, Abdul Nasser Hasibuan ${ }^{2}$, Idris Saleh ${ }^{3}$, M. Fauzan ${ }^{4}$

diproses lebih lanjut. Data yang digunakan pada

penelitian ini bersumber dari statistik perbankan syariah yang diterbitkan Bank Indonesia tahun 2014-2018.

5. Teknik Pengumpulan Data

Teknik merupakan alat yang digunakan untuk mengumpulkan data. Data adalah segala informasi yang dijadikan dan diolah untuk suatau kegiatan penelitian sehingga dapat dijadikan sebagai dasar dalam pengambilan keputusan. Adapun teknik pengumpulan data dalam penelitian ini dapat diperoleh dengan:

\section{a. Dokumentasi}

Data dokumentasi yang digunakan dalam penelitian ini adalah data laporan keuangan yang meliputi laporan laba rugi dan neraca dari situs resmi Bank Indonesia, yakni www.bi.go.id.

b. Studi Kepustakaan

Adapun studi kepustakaan yang digunakan dalam penelitian ini adalah dengan sumber jurnal, skripsi, dan bukubuku perbankan syariah atau buku-buku yang terkait dengan variabel penelitian.

6. Teknik Analisis Data
POINT Vol. 2, No. 2, Des 2021

Setelah data terkumpul dari hasil pengumpulan data, maka akan dilakukan analisis data. Adapun metode analisis data yang akan digunakan adalah dengan bantuan SPSS 23 sebagai alat hitung.

Adapun teknik analisa data yang digunakan dalam penelitian ini adalah:

1. Uji Statistik Deskriptif

Analisis Statistik Deskriptif merupakan metode statistik yang bertugas mempelajari tata cara pengumpulan, pencatatan, penyusunan, dan penyajian data penelitian dalam bentuk tabel frekuensi atau grafik dan selanjutnya dilakukan pengukuran nilai-nilai statistikya, seperti mean, range, nilai minimum, nilai maksimum dan standard deviasi. Pengukuran nilai statistik yang digunakan dalam penelitian ini adalah minimum, maximum, mean, dan standar deviasi.

2. Uji Normalitas

Uji normalitas bertujuan untuk menguji apakah dalam model regresi variabel terikat dan variabel bebas keduanya mempunyai disribusi normal atau tidak. Untuk mengetahui uji 
normalitas data, digunakan metode kolmogorov-smirnovdengan menggunakan taraf signifikan 0,05. Data dinyatakan berdistribusi normal jika signifikan lebih besar dari $5 \%$ atau 0,05 .

3. Uji Asumsi Klasik

Sebuah model regresi yang akan digunakan untuk melakukan peramalan. Sebuah model yang baik adalah model dengan kesalahan peramalan yang seminimal mungkin. Karna itu, sebuah model sebelum menggunakan seharusnya memenuhi beberapa asumsi, yang biasa disebut asumsi klasik.

a. Uji Multikolinearitas

Multikolinearitas berarti adanya hubungan linear yang sempurna atau pasti diantara beberapa atau semua variabel yang menjelaskan dari model regresi. Pengujian ini bertujuan untuk melihat ada tidaknya kolerasi yang tinggi antara variabel-variabel bebas dalam suatu model regresi linier berganda. Jika ada kolerasi yang tinggi diantara variabel bebasnya, maka hubungan antara variabel bebas dengan variabel terikatnya menjadi terganggu.

Deteksi multikoleniaritas dapat dilakukan dengan melihat nilai VIF (Variance Inflation Factor), jika : Jika nilai VIF $<10,00$ maka artinya tidak terjadi multikoleniaritas pada data yang di uji.

b. Uji Heteroskedastisitas Heteroskedastisitas adalah untuk melihat apakah terdapat ketidaksamaan varians dari residual untuk semua pengamatan dari model regresi linear berganda. Heteroskedastisitas adalah untuk melihat apakah terdapat ketidaksamaan varians dari residual untuk semua pengamatan dari model regresi linear berganda. Heteroskedastisitas diuji dengan menggunakan uji koefisien kolerasi Rankspearman yaitu mengkolerasikan antara absolut residual hasil regresi dengan semua variabel bebas. Bila signifikansi hasil kolerasi lebih kecil dari 0,05 (5\%) maka persamaan regresi tersebut mengandung 
heteroskedastisitas dan sebaliknya

berarti non heteroskedastisitas.

c. Autokorelasi

Uji autokolerasi merupakan

kolerasi antara anggota yang disusun

menurut waktu dan tempat. Model

regeresi yang baik seharusnya tidak

terjadi autokolerasi. Jika terjadi

autokorelasi maka persamaan tersebut

menjadi tidak baik atau tidak layak

dipakai untuk memprediksi. Dilakukan

ukuran dalam menentukan ada

tidaknya masalah autokorelasi

denganuji Durbin-Watson (DW) dengan

ketentuan sebagai berikut: Angka DW

dibawah -2 berarti ada autokolerasi

positif, Angka DW diantara -2 dan +2

berarti tidak ada autokolerasi, Angka

DW diatas +2 berarti ada autokolerasi

positif.

4. Uji Hipotesis

a. Uji Koefisien Regresi Secara parsial (Uji t)

Koefisien Regresi Secara

parsial digunakan untuk mengetahui

apakah secara parsial variabel
POINT Vol. 2, No. 2, Des 2021

independen berpengaruh secara

signifikan atau tidak terhadap variabel

dependen. Dalam hal ini untuk

mengetahui apakah secara parsial

pembiayaan Muḍāabah dan

Musyārakah berpengaruh signifikan

atau tidak terhadap pendapatan

operasional Bank Pembiayaan Rakyat

Syariah Indonesia. Kriteria pengujian:

Jika $\mathrm{t}$ hitung $<\mathrm{t}$ tabel, maka HO

diterima dan Ha ditolak, Jika t hitung >

t tabel, maka HO ditolak dan $\mathrm{Ha}$

diterima.

b. Uji Koefisien Regresi Secara Simultan (Uji F)

Uji Koefisien Regresi Secara bersama-sama digunakan untuk mengetahui apakah secara bersamasama variabel independen berpengaruh signifikan terhadap variabel dependen. Dalam hal ini untuk mengetahui apakah variabel pembiayaan Muḍārabah, dan Musyārakah berpengruh secara signifikan atau tidak terhadap pendapatan operasional Bank 
Pembiayaan Rakyat Syariah kriteria pengujiannya Jika $\mathrm{F}$ hitung $>\mathrm{F}$ tabel, maka $\mathrm{HO}$ ditolak dan Ha diterima.

5. Uji Koefisien Determinasi $\mathrm{R}^{2}$

Koefisien Determinasi ${ }^{\text {R2 }}$ mengukur seberapa jauh kemampuan model dalam menerangkan variasi variabel terikat. Nilai koefisien determinasi adalah di antara nol dan satu. Nilai $\mathrm{R}^{2}$ yang kecil berarti kemampuan variabel-variabel independen dalam menjelaskan variasi variabel dependen amat terbatas. Semakin besar nilai $R^{2}$ (mendekati 1 ), berarti variabelvariabel indevenden memberikan hampir semua informasi yang dibutuhkan untuk memprediksi variasi variabel dependen (dalam arti $1 \%$ variabel independen bisa menjelaskan variabel dependen sebesar $100 \%)$.

6. Analisis Regresi Linear Berganda

Analisis Regresi Linear Berganda adalah hubungan secara linear antara dua atau lebih variabel independen dengan variabel dependen analisis ini untuk mengetahui arah hubungan antara variabel independen dengan variabel dependen apakah masing-masing variabel independen berhubungan positif atau negatif dan untuk memprediksi nilai dari variabel dependen apabila nilai variabel independen mengalami kenaikan atau penurunan. Dihitung dengan menggunakan bentuk persamaan regresi berganda sebgai berikut:

$\mathrm{Y}=\mathrm{a}+\mathrm{b} 1 \mathrm{X} 1+\mathrm{b} 2 \times 2+\mathrm{b} 3 \times 3+\mathrm{e}$

Berdasarkan persamaan linear diatas, maka persamaan dalam penelitian ini sebagai berikut:

\section{$P o=a+\beta_{1} M_{1} d_{1}+\beta_{2} M_{1} s_{2}+e$}

Dimana:

$\begin{array}{ll}\text { Po } & =\text { pendapatanoperasional } \\ \text { a } & =\text { konstanta } \\ \beta 1 \beta 2 \beta 3 & =\text { koefisien } \\ \text { Mud } & =\text { Muḍārabah } \\ \text { Mus } & =\text { Musyārakah } \\ \text { e } & =\text { Tingkat Kesalahan (Term Of } \\ & \text { Error) }\end{array}$

\section{HASIL DAN PEMBAHASAN}

\subsection{Deskriptif Data Penelitian}

Data penelitian ini diperoleh dari laporan keuangan publikasi bulanan Bank Pembiayaan Rakyat Syariah periode januari 2016 sampai desember 2018 yang diakses dari Otoritas Jasa Keuangan melalui website www.ojk.go.id. Dalam penelitian ini menggunakan pembiayaan Muḍārabah sebagai variabel X1, Pembiayaan Istishna' sebagai variabel X2 dan pendapatan operasional sebagai variabel Y. 
1.2. Hasil Analisis Data

Penelitian yang digunakan oleh peneliti merupakan penelitian dengan mengolah data sekunder yang diperoleh dari laporan keuangan bank pembiayaan rakyat syariah periode Januari 2014Desember 2018 dari situs resmi www.ojk.go.id. Adapun metode analisis data yang akan digunakan adalah dengan bantuan SPSS 23 sebagai alat hitung.

1.3. Uji Statistik deskriptif

Tabel 4.3

Hasil Uji Statistik Deskriptif Descriptive Statistics

\begin{tabular}{|c|c|c|c|c|c|}
\hline & $\mathrm{N}$ & $\begin{array}{c}\text { Minimu } \\
\mathrm{m}\end{array}$ & $\begin{array}{c}\text { Maximu } \\
\mathrm{m}\end{array}$ & Mean & $\begin{array}{c}\text { Std. } \\
\text { Deviation }\end{array}$ \\
\hline $\begin{array}{c}\text { Mudharaba } \\
\text { h } \\
\text { musyarakah } \\
\text { pendapatan } \\
\text { operasional } \\
\text { Valid N } \\
\text { (listwise) }\end{array}$ & $\begin{array}{l}60 \\
60\end{array}$ & $\begin{array}{r}100689 . \\
00 \\
394772 . \\
00 \\
85492.0 \\
0\end{array}$ & $\begin{array}{r}189893 . \\
00 \\
837915 . \\
00 \\
178169 \\
1.00\end{array}$ & $\begin{array}{r}150297 . \\
6667 \\
684296 . \\
2833 \\
745398 . \\
2667\end{array}$ & $\begin{array}{r}24733.64 \\
424 \\
121921.2 \\
2044 \\
437648.1 \\
0524\end{array}$ \\
\hline
\end{tabular}

Sumber: Hasil pengolahan data 2019, (SPSS

Versi 23)

Berdasarkan tabel di atas diketahui bahwa jumlah sampel (N) sebanyak 60 diperoleh rata-rata variabel dimana nilai minimum pembiayaan Muḍārabah sebesar Rp.100.689.00, dan nilai minimum pembiayaan Musyārakah sebesar Rp.394.772.00, dan nilai minimum pendapatan operasional sebesar Rp.85.492.00. untuk nilai maximum pembiayaan Muḍārabah sebesar Rp.189.893.00, untuk nilai maximum pembiayaan Musyārakah sebesar Rp.837.915.00, dan nilai maximum pendapatan operasional sebesar
POINT Vol. 2, No. 2, Des 2021 Rp.1.781.691.00. rata-rata pembiayaan Muḍārabah sebesar Rp.150.297.6667, untuk rata-rata pembiayaan Musyārakah sebesar Rp.684.296.2833, rata-rata pendapatan operasional sebesar Rp.745.398.2667. untuk nilai standar deviasi pembiayaan Muḍāabah sebesar Rp.24.733.644.24, nilai standar deviasi pembiayaan Musyārakah sebesar Rp.121.921.220.44, nilai standar deviasi pendapatan operasional sebesar Rp.437.648.105.24.

1.4. Uji Normalitas

Tabel 4.4

Hasil Uji Normalitas

One-Sample Kolmogorov-Smirnov Test

\begin{tabular}{|cc|r|}
\hline & & $\begin{array}{c}\text { Unstandardized } \\
\text { Residual }\end{array}$ \\
\hline Normal Parametersa,b & Mean & 60 \\
& Std. & .0000000 \\
& Deviation & 362750.01808549 \\
Most Extreme Differences & Absolute & .071 \\
& Positive & .071 \\
& Negative & -.055 \\
Test Statistic & & .071 \\
Asymp. Sig. (2-tailed) & $.200 \mathrm{c}, \mathrm{d}$ \\
\hline
\end{tabular}

Sumber: Hasil pengolahan data 2019, (SPSS Versi 23)

Berdasarkan tabel diatas hasil uji normalitas yang dilihat dari nilai Asymp Sig (2-tailed) sebesar 0,200. Dimana nilai Signifikan adalah 0,05 dan nilai Asymp.sig.(2-tailed) yang diperoleh sebesar 0,200 artinya nilai Asymp.sig.(2tailed) yang diperoleh lebih besar dari 0,05, maka dapat disimpulkan bahwa data variabel pembiayaan Muḍārabah, pembiayaan Musyārakah, pendapatan operasional terdistribusi normal dengan menggunakan uji kolmogrow smirnow. 
1.5. Uji Asumsi Klasik

1. Uji Multikolonieritas

Tabel 4.5.1

Hasil Uji Multikolinearitas Coefficientsa

\begin{tabular}{|c|c|c|c|c|c|c|c|}
\hline \multirow[b]{2}{*}{ Model } & \multicolumn{2}{|c|}{$\begin{array}{c}\text { Unstandardized } \\
\text { Coefficients }\end{array}$} & \multirow{2}{*}{$\begin{array}{c}\begin{array}{c}\text { Standar } \\
\text { dized } \\
\text { Coefficie } \\
\text { nts }\end{array} \\
\text { Beta }\end{array}$} & \multirow[b]{2}{*}{$\mathrm{t}$} & \multirow[b]{2}{*}{ Sig. } & \multicolumn{2}{|c|}{$\begin{array}{c}\text { Collinearity } \\
\text { Statistics }\end{array}$} \\
\hline & B & $\begin{array}{l}\text { Std. } \\
\text { Error }\end{array}$ & & & & $\begin{array}{c}\text { Tolera } \\
\text { nce }\end{array}$ & VIF \\
\hline $\begin{array}{cc}1 & \text { (Const } \\
& \text { ant) }\end{array}$ & $\begin{array}{r}- \\
64239 \\
3.243\end{array}$ & $\begin{array}{r}306814 . \\
231\end{array}$ & & $\begin{array}{r}2.09 \\
4\end{array}$ & .041 & & \\
\hline $\begin{array}{c}\text { Mudh } \\
\text { araba } \\
\text { h }\end{array}$ & 286 & 2.863 & .016 & .100 & .921 & .460 & $\begin{array}{r}2.1 \\
72\end{array}$ \\
\hline $\begin{array}{l}\text { musya } \\
\text { rakah }\end{array}$ & 1.965 & .581 & .547 & $\begin{array}{r}3.38 \\
4\end{array}$ & .001 & .460 & $\begin{array}{r}2.1 \\
72\end{array}$ \\
\hline
\end{tabular}

Sumber: Hasil pengolahan data 2019, (SPSS Versi 23)

Berdasarkan tabel diatas hasil uji multikolinearitas yang dilihat dari nilai VIF (Variance Inflation Factor) Dari pembiayaan pembiayaan Muḍārabah dan pembiayaan Musyārakah sebesar 2.172, dan toleransi dari kedua variabel sebesar 0.460 . ini berarti nilai VIF dari kedua variabel kurang dari 10 dan nilai toleransi kedua variabel lebih dari 0,1. Maka dapat disimpulkan bahwa antara variabel pembiayaan Muḍārabah dan pembiayaan Musyārakah ini bebas dari multikolinearitas.

2. Uji Heteroskedastisitas

Tabel 4.5.2

Hasil Uji Heteroskedastisitas

\begin{tabular}{|c|c|c|c|c|c|}
\hline \multicolumn{6}{|c|}{ Correlations } \\
\hline & & & $\begin{array}{c}\text { mudhar } \\
\text { abah }\end{array}$ & $\begin{array}{c}\text { Musyara } \\
\text { kah }\end{array}$ & $\begin{array}{l}\text { Unstandardi } \\
\text { zed Residual }\end{array}$ \\
\hline \multirow[t]{7}{*}{$\begin{array}{l}\text { Spearm } \\
\text { an's rho }\end{array}$} & $\begin{array}{c}\text { mudhar } \\
\text { abah }\end{array}$ & $\begin{array}{l}\text { Correlation } \\
\text { Coefficient }\end{array}$ & 1.000 & & \\
\hline & & $\begin{array}{l}\text { Sig. (2- } \\
\text { tailed) }\end{array}$ & & .000 & .796 \\
\hline & & $\mathrm{N}$ & 60 & 60 & 60 \\
\hline & $\begin{array}{c}\text { musyara } \\
\text { kah }\end{array}$ & $\begin{array}{l}\text { Correlation } \\
\text { Coefficient }\end{array}$ & $.648^{* *}$ & 1.000 & \\
\hline & & $\begin{array}{l}\text { Sig. (2- } \\
\text { tailed) }\end{array}$ & .000 & & .469 \\
\hline & & $\mathrm{N}$ & 60 & 60 & 60 \\
\hline & $\begin{array}{l}\text { Unstand } \\
\text { ardized }\end{array}$ & $\begin{array}{l}\text { Correlation } \\
\text { Coefficient }\end{array}$ & .034 & .095 & 1.000 \\
\hline
\end{tabular}

\begin{tabular}{|lc|r|r|r|}
\hline Residual & $\begin{array}{l}\text { Sig. (2- } \\
\text { tailed) }\end{array}$ & .796 & .469 & \\
& $\mathrm{~N}$ & 60 & 60 & 60 \\
\hline
\end{tabular}

Sumber: Hasil pengolahan data 2019, (SPSS Versi 23)

Berdasarkan tabeldiatas menunjukkan bahwa variabel yang di uji tidak mengandung heteroskedastisitas karena dilihat dari variabel Muḍārabah (X1)dari sig. 2-tailed terhadap residual adalah 0,796 kemudian Musyārakah (X2) Sig. 2-tailed terhadap residual adalah 0,496 dilihat darisignifikansi hasil kolerasi lebih besar dari 0,05 (5\%). Sehingga bila data diperbesar tidak menyebabkan kesalahan semakin besar pula.

\section{Uji Autokolerasi}

Tabel IV.5

Hasil Uji Autokolerasi

Model Summaryb

\begin{tabular}{|c|c|r|r|r|r|}
\hline Model & $\mathrm{R}$ & $\begin{array}{c}\mathrm{R} \\
\text { Square }\end{array}$ & $\begin{array}{c}\text { Adjusted R } \\
\text { Square }\end{array}$ & $\begin{array}{c}\text { Std. Error of } \\
\text { the Estimate }\end{array}$ & $\begin{array}{c}\text { Durbin- } \\
\text { Watson }\end{array}$ \\
\hline 1 & $.559 a$ & .313 & .289 & $\begin{array}{r}369059.1870 \\
4\end{array}$ & .738 \\
\hline
\end{tabular}

Sumber: Hasil pengolahan data 2019, (SPSS Versi 23)

Pada tabel hasil uji DW di atas, bahwa tidak terjadi autokolerasi hal ini dijelaskan pada penentuan pengambilan keputusan autokolerasi, bahwa DW 0,738 . Hal ini dikarenakan nilai Durbin watson berada pada posisi antara -2 dan $+2(-2<0,738<+2)$.

1.6. Uji Hipotesis

1. Uji Koefisien Determinasi (R2) 
Tabel 4.6.1

Hasil Uji Koefisien Determinasi (R2)

Model Summaryb

\begin{tabular}{|c|c|r|r|r|r|}
\hline Model & $\mathrm{R}$ & $\begin{array}{c}\mathrm{R} \\
\text { Square }\end{array}$ & $\begin{array}{c}\text { Adjusted R } \\
\text { Square }\end{array}$ & $\begin{array}{c}\text { Std. Error of } \\
\text { the Estimate }\end{array}$ & $\begin{array}{c}\text { Durbin- } \\
\text { Watson }\end{array}$ \\
\hline 1 & .559 & .313 & .289 & 369059.18704 & .738 \\
\hline
\end{tabular}

Sumber: Hasil pengolahan data 2019, (SPSS Versi 23)

Berdasarkan tabel hasil uji Koefisien Determinasi $\left(R^{2}\right)$ menunjukkan bahwa besarnya nilai Adjusted R Square dikeahui 0,289 atau sama dengan 28,9 persen. Artinya hanya 28,9 persen variabel pembiayaan Muḍārabah dan pembiayaan Musyārakah secara bersama-sama mempengaruhi pendapatan operasional. Sementara kurangnya sebesar 71,1 persen dipengaruhi oleh faktor lain diluar model regresi yang diteliti oleh peneliti. Adapun faktor tersebut yaitu berasal dari pembiayaan dengan akad jual beli Murābahah, Salam, Istishna', serta akad sewa ljarah, ljarah muntahiya bit tamlik dan Qord.

2. Uji Koefisien Regresi Secara Varsial (Uji t)

Tabel IV.7

Uji Koefisien Regresi Secara Varsial (Uji t) Coefficientsa

\begin{tabular}{|c|c|c|c|c|c|}
\hline \multirow[b]{2}{*}{ Model } & \multicolumn{2}{|c|}{$\begin{array}{l}\text { Unstandardize } \\
\text { d Coefficients }\end{array}$} & \multirow{2}{*}{$\begin{array}{c}\begin{array}{c}\text { Standar } \\
\text { dized } \\
\text { Coeffici } \\
\text { ents }\end{array} \\
\text { Beta } \\
\end{array}$} & \multirow[b]{2}{*}{$\mathrm{t}$} & \multirow[b]{2}{*}{ Sig. } \\
\hline & B & $\begin{array}{l}\text { Std. } \\
\text { Error }\end{array}$ & & & \\
\hline $\begin{array}{c}1 \text { (Consta } \\
\text { nt) }\end{array}$ & $\begin{array}{r}- \\
642393 \\
.243\end{array}$ & $\begin{array}{r}30681 \\
4.231\end{array}$ & & $\begin{array}{r}2.09 \\
4\end{array}$ & .041 \\
\hline $\begin{array}{l}\text { Mudha } \\
\text { rabah }\end{array}$ & .286 & 2.863 & .016 & .100 & .921 \\
\hline $\begin{array}{c}\text { musyar } \\
\text { akah }\end{array}$ & 1.965 & .581 & .547 & $\begin{array}{r}3.38 \\
4\end{array}$ & .001 \\
\hline
\end{tabular}

Sumber: Hasil pengolahan data 2019, (SPSS Versi 23)
POINT Vol. 2, No. 2, Des 2021 Berdasarkan uji parsial diperoleh hasil output antara lain thitung pembiayaan Muḍārabah sebesar 0,100, sedangkan thitung pembiayaan Musyārakah sebesar 3,384. Tabel distribusi t dicari dengan derajat kebebasan (df) $n-k-1$ atau 60-2-1=57 dimana ( $\mathrm{n}$ adalah jumlah sampel dan $\mathrm{k}$ adalah jumlah variabel indevenden). Pada pembiayaan Muḍārabah nilai $\mathrm{t}_{\text {hitung }}$ $<t_{\text {tabel }}(0,100<2,0024)$ maka $\mathrm{H} 01$ diterima dan Ha1 ditolak, artinya tidak terdapat pengaruh antara pembiayaan Muḍārabah dengan pendapatan operasional. Sedangkan pada pembiayaan Musyārakah nilai $t_{\text {hitung }}>$ $t_{\text {tabel }}(3,384>2,00247)$ maka HO2 ditolak dan Ha2 diterima, artinya terdapat pengaruh antara pembiayaan Musyārakah dengan pendapatan operasional.

3. Uji Koefisien Regresi Secara Simultan (Uji F)

Tabel IV.8

Hasil Uji Koefisien Regresi Secara Simultan (Uji F) ANOVAa

\begin{tabular}{|c|c|c|c|c|c|c|}
\hline & Model & $\begin{array}{l}\text { Sum of } \\
\text { Squares }\end{array}$ & Df & $\begin{array}{c}\text { Mean } \\
\text { Square }\end{array}$ & $\mathrm{F}$ & Sig. \\
\hline \multirow[t]{3}{*}{1} & Regression & $\begin{array}{r}3536949015 \\
573.222\end{array}$ & 2 & $\begin{array}{r}17684745 \\
07786.611\end{array}$ & $\begin{array}{r}12.98 \\
4\end{array}$ & $.000 \mathrm{~b}$ \\
\hline & Residual & $\begin{array}{r}7763666961 \\
640.510\end{array}$ & 57 & $\begin{array}{r}13620468 \\
3537.553\end{array}$ & & \\
\hline & Total & $\begin{array}{r}1130061597 \\
7213.732\end{array}$ & 59 & & & \\
\hline
\end{tabular}

Sumber: Hasil pengolahan data 2019, (SPSS Versi 23)

\section{Berdasarkan hasil output uji F di}

atas diketahui bahwa nilai Ftitung sebesar 12,984 dengan nilai Sig. sebesar 
0.000. nilai $F_{\text {hitung }}$ dibandingkan dengan

$F_{\text {tabel }}$ diketahui nilai df1=2 dan df2=57.

Nilai ftabel dicari dengan rumus df1=k-1 dan df2=n-k dimana ( $k$ adalah jumlah variabel dan $\mathrm{n}$ adalah jumlah sampel) yang menghasilkan ni Ftabel sebesar 3,16 . Hal ini menunjukkan bahwa $F_{\text {hitung }}$ memiliki nilai yang lebih besar dari $F_{\text {tabel }}$ $(12,984>3,16)$. Maka dari itu $\mathrm{HO}_{3}$ ditolak dan $\mathrm{Ha}_{3}$ diterima dimana pembiayaaan Muḍārabah dan pembayaan Musyārakah mempunyai pengaruh yang signifikan secara simultan terhadap pendapatan operasional.

1.7. Analisis Regresi Linear Berganda

Tabel 4.7

Hasil Uji analisis Regresi Linier Berganda

\begin{tabular}{|c|c|c|c|c|c|c|}
\hline \multirow{2}{*}{\multicolumn{2}{|c|}{ Model }} & \multicolumn{2}{|c|}{$\begin{array}{l}\text { Unstandardized } \\
\text { Coefficients }\end{array}$} & \multirow{2}{*}{$\begin{array}{c}\text { Stand } \\
\text { ardize } \\
d \\
\text { Coeffi } \\
\text { cients }\end{array}$} & \multirow[b]{2}{*}{$\mathrm{t}$} & \multirow[b]{2}{*}{ Sig. } \\
\hline & & B & $\begin{array}{l}\text { Std. } \\
\text { Error }\end{array}$ & & & \\
\hline & (Constant) & $\begin{array}{r}642393 . \\
243\end{array}$ & $\begin{array}{r}306814 . \\
231\end{array}$ & & -2.094 & .041 \\
\hline & Mudharabah & .286 & 2.863 & .016 & .100 & .921 \\
\hline & musyarakah & 1.965 & .581 & .547 & 3.384 & .001 \\
\hline
\end{tabular}

Sumber: Hasil pengolahan data 2019, (SPSS Versi 23)

Berdasarkan analisis regresi linier berganda dapat diperoleh persamaan yaitu:

$$
P o=a+\beta 1 \text { Mud1 }+\beta 2 \text { Mus2 }+e
$$

Pend. Operasional $=-642393,243+0,286$

Muḍārabah + 1,965 Musyārakah

Dimana:

$$
\begin{array}{ll}
\text { Po } & =\text { pendapatan operasional } \\
\text { a } & =\text { konstanta } \\
\beta 1 \beta 2 & =\text { koefisien }
\end{array}
$$

Mud = Muḍārabah

Mus = Musyārakah

e $\quad=$ Tingkat Kesalahan (Term Of Error)

Maka, Berdasarkan persamaan diatas dapat diartikan bahwa:

$\mathrm{a}=$ Nilai konstanta sebesar -642.393.243 Juta menunjukkan bahwa apabila variabel pembiayaan Muḍārabah dan pembiayaan Musyārakah nilainya 0 , Maka nilai pendapatan operasional di Bank Pembiayaan Rakyat Syariah nilainya sebesar - 642.393.243 Juta.

$\beta 1=$ koefisien regresi variabel pembiayaan Muḍārabah bernilai positif sebesar 0,286, hal ini menunjukkan arah hubungan antara pembiayaan Muḍārabah dengan pendapatan operasional. Setiap kenaikan pembiayaan Muḍārabah 1 Juta, maka pendapatan operasonal akan mengalami peningkatan sebesar 286.000 Juta dengan asumsi variabel independen lain nilainya tetap.

$\beta 2=$ koefisien regresi variabel pembiayaan Musyārakah bernilai positif sebesar 1,965, hal ini mununjukan arah hubungan antara pembiayaan Musyārakah dengan pendapatan operasional. Setiap kenaikan pembiayaan musyārakah sebesar 1 Juta, maka pendapatan operasional mengalami peningkatan sebesar 1.965.000 Juta dengan asumsi variabel independen lainnya tetap. 
Mariati $^{1}$, Abdul Nasser Hasibuan ${ }^{2}$, Idris Saleh ${ }^{3}$, M. Fauzan ${ }^{4}$

A. Pembahasan Hasil Penelitian

Penelitian ini berjudul pengaruh pembiayan Muḍārabah dan pembiayaan 2. Musyārakah terhadap pendapatan operasional pada Bank Pembiayaan Rakyat Syariah (BPRS) di Indonesia Periode 2014-2018. Dari hasil penelitian yang sudah tertera di atas dengan menggunakan SPSS versi 23 menunjukkan bahwa hasil dari persamaan regresi yang digunakan sudah cukup baik, karena sudah memenuhi syarat yaitu data yang diuji terdapat berdistribusi normal, tidak terjadi multikoleniaritas, tidak terjadi heteroskedastisitas dan tidak terjadi autokolerasi.

1. Pengaruh Pembiayaan Muḍārabah Terhadap Pendapatan Operasional pada Bank Pembiayaan Rakyat Syariah.

Hasil penelitian menunjukkan bahwa pembiayaan muḍārabah tidak berpengaruh terhadap pendapatan operasional pada Bank Pembiayaan Rakyat Syariah.karenanilai thitung < ttabel $(0,100<2,0024)$, maka H01 diterima dan Ha1 ditolak.

Hasil penelitian ini sejalan dengan penelitian Cut Faradilla dkk, yang berjudul Pengaruh Pembiayaan Murabahah, Istishna, ljarah, Muḍārabah dan Musyārakah Terhadap 3. Profitabilitas Bank Umum Syariah Di Indonesia (Cut Faradilla dkk: 2017).

Penelitian ini juga mendukung oleh penelitian Rivalah Anjani Muḍārabah tidak berpengaruh terhadap pendapatan operasional pada Bank Pembiayaan Rakyat Syariah di Indonesia(Rivalah Anjani: 2016).

Pengaruh Pembiayaan Musyārakah Terhadap Pendapatan Operasional pada Bank Pembiayaan Rakyat Syariah Secara Parsial.

Hasil penelitian menunjukkan bahwa pembiayaan Musyārakah berpengaruh terhadap pendapatan operasional pada Bank Pembiayaan Rakyat Syariah karena thitung > ttabel $(3,384$ > 2,00247), maka H02 ditolak dan Ha2 diterima.

Hasil penelitian ini juga sejalan dengan teori yang ada dalam buku Ismal "Perbankan Syariah" yaitu pembiayaan yang diberikan oleh bank kepada nasabah akan berpengaruh pada peningkatan profitabilitas bank. Hal ini dapat dicerminkan pada pendapatan bank (Ismail: 2011).

Penelitian ini juga didukung oleh penelitian terdahulu yang dilakukan oleh Rivalah Anjani yang bejudul "Pengaruh pembiayaan muḍārabah, Musyārakah, dan murahahah terhadap propitabilitas BPRS di Indonesia periode 2012-2015". Dimana hasil dari penelitiannya pembiayaan Musyārakah berpengaruh terhadap profitabilitas bank(Rivalah Anjani: 2016).

Pengaruh Pembiayaan Muḍārabah dan Pembiayaan Musyārakah Terhadap Pendapatan Operasional pada Bank Pembiayaan Rakyat Syariah.

Hasil uji F menunjukkan bahwa pembiayaan muḍārabah dan pembiayaan Musyārakah mempunyai pengaruh secara 
simultan terhadap pendapatan operasional, hal ini dapat dilihat dari hasil uji F, dimana Fhitung memiliki nilai yang lebih besar dari Ftabel (12.984>3,16), maka HO3 ditolak dan $\mathrm{Ha}$ diterima.

Penelitian ini sejalan dengan penelitian Rivalah Anjani yang berjudul pengaruh pembiayaan Muḍārabah, Musyārakah dan murabahah terhadap profitabitas BPRS di Indonesia priode 2012-2015.

Penelitian ini juga didukung oleh penelitian yang dilakukan oleh Cut Faradilla, dkk dengan judul "Pengaruh Pembiayaan Murabahah, Istishna, Ijarah, Muḍārabah dan Musyārakah Terhadap Profitabilitas Bank Umum Syariah Di Indonesia. "Hasil penelitiannya menunjukkan bahwa secara simultan variabel Murabahah, Istishna, Ijarah, Muḍārabah dan Musyārakah berpengaruh signifikan terhadap pendapatan operasional. Sedangkan secara varsial istishna, ijarah, muḍārabah tidak berpengaruh signifikan terhadap pendapatan operasional.

\section{PENUTUP}

\section{Kesimpulan}

Berdasarkan hasil pengolahan data pada penelitian ini yang berjudul "pengaruh pembiayaan Muḍārabah dan pembiayaan Musyārakah terhadap pendapatan operasional Pada Bank Pembiayaan Rakyat Syariah Periode 2014-2018", Dapat disimpulkan bahwa: Tidak terdapat pengaruh pembiayaan Muḍārabah terhadap pendapatan operasional pada Bank Pembiayaan Rakyat Syariah di Indonesia periode 2014-1018. Hal ini dibuktikan dengan nilai thitung $<$ ttabel $(0,100<2,0024)$. Terdapat pengaruh pembiayaan Musyārakah terhadap pendapatan operasional Bank Pembiayaan Rakyat Syariah di Indonesia periode 2014-2018. Hal ini dibuktikan dengan nilai thitung $>$ ttabel $(3,384>2,00247)$. Berdasarkan uji simultan (F) maka yang diperoleh adalah Fhitung memiliki nilai yang lebih besar dari Ftabel $(12.984>3,16)$, hal ini menjelaskan bahwa pembiayaaan Muḍārabah dan pembiayaan Musyārakah mempunyai pengaruh yang signifikan secara simultan terhadap pendapatan operasional.

\section{Saran}

Semoga adanya pengetahuan masyarakat terhadap minat produk perbankan syariah

\section{DAFTAR PUSTAKA}

Abdul Nasser Hasibuan, Jurnal Imara, "Strategi pemasaran produk funding di PT. Bank pembiayaan rakyat syariah padangsidimpuan", 2018.

Ali Hardana, Jurnal Al Masharif, "Model Pengembangan Kewirausahaan Di Perguruan Tinggi", 2018.

Agus Iriyanto, Statistik Konsep Dasar Aplikasi, dan Pengembangannya , Jakarta: Kencana Prenada Media Group, 2004

Al Hadi Abu Azam, Fikih Muamalah Kontemporer, Depok: Rajawali Pers, 2017

Bambang Prasetyo dan Lina Miftahul Jannah, Metode Penelitian Kuantitatif: Teori dan Aplikasi, Jakarta: PT. Rajagrafindo Persada, 2007 
Duwi Priyatno, Belajar Cepat Olah Data Statistik Dengan SPSS, Yogyakarta: CV. Andi Offset, 2012

H. Zainuddin Ali, Hukum Perbankan Syariah, Jakarta: Sinar Grafika, 2008

Hasibuan Melayu, S.P, Dasar-Dasar Perbankan, Jakarta: Bumi Aksara, 2004

Husein Umar, Metode Penelitian untuk Skripsi dan Tesis Bisnis, Jakarta: Rajawali Pers, 2013

Imam Ghozali, Aplikasi Aanalisis Multivariat Dengan Program SPSS, Semarang: Universitas Diponegoro, 2006

Ismail, Perbankan Syariah Jakarta: Kencana, 2011

Jonathan Sarwono, Rumus-Rumus Popular SPSS 22 untuk Riset Skripsi Yogyakarta: Cv Andi Offset, 2015

Kautsar Riza Salman, Akuntansi Perbankan Syariah Berbasis Psak Syariah Padang: Akademia, 2012

M. Sulhan Dan Ely Siswanto, Menajemen Bank Konvensional dan Syariah, Malang: UIN Malang Press, 2008

Mudrajad Kuncoro, Metode Riset untuk Bisnis dan Ekonomi , Jakarta: Erlangga, 2009

Singgih Santoso, Panduan Lengkap SPSS Versi 23, Jakarta: Elex Media Komputindo, 2016

Sugiyono, Metode Penelitian Bisnis, Bandung: Alfabeta, 2005
POINT Vol. 2, No. 2, Des 2021

Sutan Remy Sjahdeini, Perbankan Syariah , Jakarta: Kencana, 2014

Sumber Skripsi

Muhammad Jimmy Anshor Sinaga, Pengaruh Pembiayaan dan Dana Pihak Ketiga Terhadap Pendapatan Operasional (Studi pada PT. Bank Syariah Mandiri, Tbk), (Skripsi, Padangsidimpuan: IAIN, 2016)

Rivalah Anjani, Pengaruh Pembiayaan Mudharabah, Musyarakah, dan Murahahah Terhadap Propitabilitas (Studi BPRS di Indonesia Periode 20122015), Skripsi, Univesitas Muhammadiyah Surakarta 2016

\section{Sumber Jurnal}

Cut Faradilla, Dkk , Pengaruh Pembiayaan Murabahah, Istishna', ljarah, Muḍārabah Terhadap Profitabilitas Bank Umum Pembiayaan Syariah Di Indinesia, Jurnal Universitas Syiah Kuala, 2017

Mahbud, M.Ag, Pengaruh Pembiayaan Muḍārabah Terhadap Pendapatan BMT UGT Sidogiri Capem Songgon Kabupaten Banyuwangi (Jurnal Institut Agama Islam (IAI) Darussalam Blokagung, 2016

Sumber Lainnya

http://www.bprs-bdw.co.id/tentang-kami/visidan-misi

http;www.BPRS/tentang struktur organisasi BPRS

www.bi.go.id 